\title{
Evolution View of Entrepreneurial Mindset Theory
}

\author{
Konan Kan Elvis Kouakou \\ School of Management \\ Jiangsu University \\ Zhenjiang, China \\ Cai Li \\ Jiangsu University \\ Zhenjiang, China 212013 \\ Isaac Gumah Akolgo \\ School of Management \\ Jiangsu University \\ Zhenjiang, China
}

\author{
Alida Magakam Tchamekwen \\ School of Finance and Economics, \\ Jiangsu University, Zhenjiang \\ China
}

\begin{abstract}
Unemployment is one of the significant trends that hamper the economic development of the country and the well-being of people. However, the embracement of an entrepreneurship career is mainly conditioned by the high rate of unemployment and the nonsatisfaction of a current employee. Entrepreneurship career requires the development of an entrepreneurial mindset through an interactive process.Therefore the study aims to synthesize the finding of preview researches on the content and process of an entrepreneurial mindset. Hence the consolidation of the current state of the literature on entrepreneurial mindset concept to understand its origins, roots, and evolution. Scholars want to instill an entrepreneurial mindset to students at their youngest age. By doing so, they develop entrepreneurial experiences, skills, and abilities to overcome entrepreneurial challenges. This article offers a clear insight into the topic of an entrepreneurial mindset to ease individuals and organization involved in interactive entrepreneurial activities continuously.
\end{abstract}

Keywords: Entrepreneurship; Entrepreneurial mindset; Cognitive psychology; Personality traits; Mindset theory; Entrepreneurial mindset profile (EMP)

\section{Introduction}

The emersion of entrepreneurship as a research field has appealed a substantial amount of scholars around the world, within a few decades(Audretsch, Kuratko, \& Link, 2016; Bruton, Ahlstrom, \& Obloj, 2008; Busenitz et al., 2003; Déry \& Toulouse, 1996; Hindle \& Moroz, 2010; Schildt, 2012; Welter \& Lasch, 2008). The entrepreneurs with their crucial role in economic growth, poverty alleviation, revenue generation, wealth creation, and job creation represent the mainstay of economic structure(Romer, 1994). They develop the potential to convert innovation into a new, efficient and valuables goods and services through the exploitation of their distinct attributes and contribute to the economic development of the country (Schumpeter, 1934). A dynamic economy requires a higher number of young people who are willing and able to become entrepreneurs. Scholars posit that successful future strategists will exploit the entrepreneurial mindset. A full embracement of the entrepreneurial mindset is driven by way of acting and thinking like a habitual entrepreneur (McGrath \& MacMillan, 2000).

Entrepreneurial mindset as a concept is gradually emerging in the field of entrepreneurship and plays a significant role in the process of nurturing the entrepreneurial skills and capabilities of students. Thus entrepreneurial mindset through entrepreneurship education is the mean needed first to gain the attention of the students. Therefore it is evident that entrepreneurial education has the potential to transfer and communicate to the students the skills, ability, and knowledge necessary to identify potential business opportunities (Chinonye \& Akinlabi, 2014). 
Scholars conducted a significant amount of research work on the topic of an entrepreneurial mindset to help students, individuals, and organizations overcome their entrepreneurial challenges in order to become more entrepreneurial and increase entrepreneurial outcomes and activities.

Entrepreneurial mindset and organization culture studies facilitate the identification of individuals and organization which are susceptible to be more entrepreneurial and more likely to engage in entrepreneurial action. The inclination to discover, evaluate and exploit opportunities refers to the entrepreneurial mindset. Furthermore, the perception of an entrepreneurial mindset lies into the ability to sense, act and mobilize under uncertain condition rapidly (Haynie, Shepherd, Mosakowski, \& Earley, 2010). It is the state of mind of an entrepreneur which allows him to analyze the world and the opportunities and possibilities that it offers (Reed \& Stoltz, 2011).

This article aims to synthesize the finding of preview researches on the content and process of an entrepreneurial mindset. Hence the consolidation of the current state of the literature on entrepreneurial mindset concept to understand its origins, roots, and evolution. This paper is a review of literature which intends to provide a better understanding of the entrepreneurial mindset concept. A clear insight of an entrepreneurial mindset will go through an in-depth elaboration of several key subtopics discussed by scholars.

\section{1- Entrepreneurship}

\subsection{Genesis of entrepreneurship}

Entrepreneur is a French word which had its first appearance in the literature in 1253. At that time it was used in different forms. The term Entrepreneur was inspired by the French verb "entreprendre" which means "undertaker" as in the sense of someone undertaking a significant project.The history of an entrepreneur has started with the philosophical thinking of three authors. Richard Cantillon, Jean Baptiste say, and Joseph Alois Schumpeter through their various writings were the foremost pioneers that firstly reflect extensively on the role of entrepreneur. Therefore dig into the writings of these three pioneers is the easiest way to comprehend the concept of an entrepreneur at different point of view.

\subsection{Three pioneers in the field of entrepreneurship}

Cantillon Richard was a French venture capitalist seeking an investment opportunity that can produce more than the average yields. As an investor, Cantillon perceived the element of risk as a core aspect of entrepreneurial projects and took it in consideration of what he meant by being an entrepreneur (Cantillon, 1755). According to Alois Joseph Schumpeter, the function of an entrepreneur was evident in the mind of Cantillon,but that time nobody has entirely formulated it. According to Cantillon(1755), the word entrepreneur refers to a person who initially gets an idea to purchase raw material at a well-known price and sell it at an unknown price to make some profit. Through the definition formulated by Cantillon, we can visualize the intermediary role attributed to the entrepreneur while instigating a change.

Jean-Baptiste Say is the second authors that had significantly contributed to the field of entrepreneurship. Besides, being a prolific writer, Jean Baptiste Say is an entrepreneur that belongs to an entrepreneurial family who identified the element of innovation as the most characteristic of becoming an entrepreneur. Through his writing, he intended to convince people of the massive impact of the entrepreneur in the development of an economy. Therefore Say emphasizes his writing on how to stimulate people desires to be an entrepreneur. He viewed entrepreneurs as being individuals who could do new things, individuals who could accomplish more with less, and individuals who might acquire more by achieving something in another or diverse way(Say, 1815, 1996). In this way, Say perceives the entrepreneur as an economic player whose exercises produced an added value. Schumpeter underlined that Say was the first to draw a distinct contrast between the role played by both the entrepreneur and capitalist, in his most exceptional work on the history of economic (Schumpeter, 1954).

The experts have allocated Schumpeter as the author with relevant work on the association between entrepreneurs and innovation. By taking over the proposed entrepreneur definition by Say, he posits that the perception and the exploitation of new opportunities is the essence of entrepreneurship (Schumpeter, 1928). The visit to the AustralianHungarian empire made Schumpeter more dynamic in the definition of the role played by an entrepreneur. Thus he indicated that the revitalization of the economy and the organization mostly requires the need of an entrepreneur. A century after, the thing beyond the writing of Schumpeter tend to be more complex and more complete. Therefore Schumpeter (1934) connected innovation by the entrepreneur with five components that are; the introduction of new goods, the introduction of new methods application, the opening of a new market, the takeover of a source of supply of raw material, and the carrying out the new organization of industry. 
The observation of inclusion of the term new venture creation in the proposed definition of innovation by Schumpeter made his work fascinated. Schumpeter writings frequently referenced the concept of creative destruction to allude the contribution of change by the entrepreneur. During Schumpeter's lifetime, the term entrepreneur was used to allude to what in the present day is called intrapreneur.

The reflection of the three pioneers was based on the term entrepreneur, the role, and the characteristics that define an entrepreneur. Their thoughts have contributed to the creation of a considerable database that helps many authors to build upon it.

\subsection{Defining the theory of entrepreneur (ship).}

The field of entrepreneurship does not come under a specific definition. The domain has addressed by different scholars adhering to different conceptualizations. From a perspective point, there is no unique and best absolute of defining an entrepreneur and its roles. Therefore scholars formulate their definition of entrepreneurship according to their standpoint or perspectives. Thus Taylor (1947) said that just like there is no one best way. From the table1 and figure 1, we observe that seven(7) components have been the emphasis element of several prominent authors while formulating their definitions of entrepreneur or entrepreneurship. Those elements were regrouped into three different levels which demonstrated the level of importance of those components while preparing a definition of an entrepreneur. Scholars have identified opportunity recognition as the essential characteristics of an entrepreneur according to the analysis of the table and figure above. Therefore the definition of an entrepreneur or entrepreneurship should firstly start by opportunity recognition before adding the rest of the components. That's why given these all definitions, Shane and Venkataraman's definition is significant. Still, scholars agree that opportunity recognition and exploitation of the entrepreneurial opportunity are the heart of entrepreneurship.

\section{2- Entrepreneurial mindset}

\subsection{A shared definition of entrepreneurial mindset theory}

The notion of an entrepreneurial mindset is being referenced by the state of mind that change the status of an individual into an entrepreneur. Therefore an individual becomes an entrepreneur thanks to its state of mind which allows him to analyze the world and the opportunities and possibilities that it offers (Reed and Stoltz, 2011). According to Ferrero and Fioro(2014), entrepreneurship mindset is all about the analysis of the world, its opportunities and possibilities, also the understanding how an individual can contribute to the construction and progress of the economic and social system and finally the conversion of ideas into action to attain objectives. Mcgrath and MacMillan(2000) formulated an entrepreneurial mindset definition based on three factors; the ability to sense, the ability to act rapidly, and the ability to mobilize resources even under unsettled conditions. Furthermore, the perception of an entrepreneurial mindset as a growth-oriented perspective is another way to define it. Haynie et al.(2010) develop a situating metacognitive method of entrepreneurial mindset based on the definition that this concept refers to the ability to sense, act and mobilize under uncertain condition rapidly. Then Valerio et al. (2014) come out with their definition of entrepreneurial mindset which has been referenced as the socio-emotional skills and overall awareness of entrepreneurship associated with entrepreneurial motivation and future success as an entrepreneur.

\subsection{Exploring the entrepreneurial mindset}

Entrepreneurship spirit or entrepreneurial initiative can be used to frame entrepreneurship insofar as those terms describe the whole idea behind entrepreneurship. Doing entrepreneurship business implies that an individual has to determine and utilize opportunities proposed by the environment. Entrepreneurial spirit also denoted as an entrepreneurial mindset is an innovative practice which leads to discover and evolve opportunities and then set up the right behavior to effectively exploit those opportunities. Therefore the establishment of an entrepreneurial mindset become primordial to restore the competitive spirit of economic entities as well as the socio-economic lifestyle of people. It will enhance value creation and job formation (Thompson, 2004). The entrepreneurial mindset in education purpose help students access to an entrepreneurship education course and facilitate the development of teaching method to spread the entrepreneurial awareness and gain entrepreneurial skills. Although Ireland, Hitt, \& Sirmon(2003) concluded that an entrepreneurial mindset could facilitate the promotion of flexibility, creativity, ongoing innovation, and renewal. This situation based on learning processes to the improvement of the cognitive oscillation of the human mind generates the movement from a unique individual nature. Building a metacognitive model of entrepreneurial mindset on the cognitive skills was to shift the attention from interrogating the cognitive abilities that individuals utilize to define entrepreneurial opportunities to the process through which entrepreneur promote and acquaint higher-order cognitive strategies or metacognition (Haynie et al., 2010). Therefore they conceptualize the cognitive skills model of entrepreneurial mindset base upon situating metacognitive abilities approach. 
Self-efficacy has been the needed element within the cognitive and metacognitive abilities approach that may be considered as a fundamental prerequisite to strengthen and efficiently promulgate the entrepreneurial mindset (Mauer, Neergaard, \& Kirketerp, 2009). Self-efficacy is a complex psycho-social that can be used to enhance entrepreneurship education. It is not perceived as an inborn trait and has clear benefits of yielding risk and uncertainty. Entrepreneurial mindset through its elaboration brought by the personality traits, cognitive abilities, and the metacognitive process has been admitted useful in entrepreneurship education especially in business oriented and arts area (Pollard \& Wilson, 2014).

An individual who efficacy transform an entrepreneurial process through the mean of entrepreneurial mindset demonstrated how important mean represents the custody of an entrepreneurial mindset (McGrath and MacMillan, 2000). Furthermore, it is one of the critical features to be considered in the success or failure of SME 's. It means that a business without entrepreneurial mindset adoption is more susceptible to fail than succeed (Dhliwayo \& Van Vuuren, 2007). A successful business environment needs the presence of entrepreneurial mindset to help the manager in their process of outgrowing old management principles to cut down the high rate of business's failure (Kuratko, 2002). Thus, the development of a creative mindset within the organization is suitable to set up innovation purpose, take advantage of the market and add value to the business (Faltin, 2007). Many researchers have significantly contributed to the evolution of the entrepreneurial mindset concept. According to the review of various research, the perception of entrepreneurial mindset includes two dimensions. Therefore entrepreneurial mindset development is connected to personality and cognitive psychology.

\subsection{Personality psychology in the development of an entrepreneurial mindset}

According to the study conducted by Cromie(2000) attributes such as the need for achievement, internal locus of control, calculated risk-taking, tolerance of ambiguity, creativity, need for autonomy and self-confidence, are mainly connected to personality. Simultaneously those several attributes have been used to run the general enterprising tendency test. This test developed by the Durham university business school is also useful to measure the one's level of motivation. Patterns of adaptive learning scales (PALS) is a set of scales that have been developed in the education sector for the identification of attributes personal achievement goal-orientation, efficacy, self-handicapping strategies, avoiding of unknown or novel options and self-presentation(Midgley et al., 2000).

The benefit of mastery-approach goals compare to the performance motivation goals is judged more in line with the theory of goal motivation and mindset formulated in the work of (Dweck \& Leggett, 1988). In the process of gaining insight into the concept of entrepreneurial personality, several studies have focused much more on the big five personality theory(Midgley, Kaplan, \& Middleton, 2001). Thus, the personality trait represents an adding value for a better understanding of entrepreneurial behavior. Whenever the study is related to the factors that affecting entrepreneurship, personality trait should be considered as an essential element of a multi-dimensional theory of variables, process and environmental(Zhao \& Seibert, 2006). Similarly, Zhao et al.(2010) argued that personality trait plays a significant role in the process of comprehending entrepreneurship but also support that this is a role where other variables must be included. According to Brandstätter(2011);Leutner, Ahmetoglu, Akhtar, \& Chamorro-Premuzic (2014), personality traits foretell an individual's intention to create and have a successful business. Therefore they pointed out the real correlation between the personality traits of the Big Five model and the success of entrepreneurial activities. However previous meta-analytical studies reveal that the innovativeness traits of the big five model foretell a better outcome compared to the conscientiousness and extroversion traits.

\subsection{Cognitive psychology in the development of an entrepreneurial mindset}

The cognitive practices that many researchers have fundamentally focus on to understand the entrepreneurial mindset are the ones that hamper adaptive cognitions in a dynamic and uncertain environment (R. K. Mitchell, Smith, Seawright, \& Morse, 2000). Mitchell et al. (2000) develop an interest in cognitive science in pursuit of a better understanding of the entrepreneurial mindset concept. Therefore they have started drawing on learnings from the cognitive science to challenge the focus on entrepreneurial personality attributed brought by various researchers in their studies. Their definition of entrepreneurial cognition regroup the knowledge structure, the judgments or decisions, also venture creations, and growth. Entrepreneurial cognition is the use of knowledge structure to make an assessment, an individual judgment or decision to evaluate the opportunity and create a business venture to achieve growth. Later on, Fayolle(2012) came out with the connection between an individual state of mind and entrepreneurial activities and outcomes. Therefore entrepreneurial mindset by definition refers to the particular state of mind which directs human conducts towards entrepreneurial activities and issues. Baron(2004)provided some suggestions to explain how cognitive psychology may append insights into critical aspects of the entrepreneurial process. 
The author investigates research which focuses on answering those three specific questions; why the choice to become an entrepreneur or not? Why some people and not others capture opportunities recognition that can lead to a productive outcome? Why do some entrepreneurs succeed and others not?

Baron (2004) closed by expressing that a cognitive perspective can demonstrate incredibly significant to the area of entrepreneurship and proposed how a broad scope of cognitive elements may show useful for future research.

\subsection{Theory of mindset: Fixed and Growth mindset}

The proposed theories of Dweck and Legget's in their earlier research denoted entity, and incremental framework has seen their names respectively change into fixed and growth mindset theories since 2006. Those new appellations are commonly used to refer to the old designation of the entity and incremental framework.

However, Dweck stated that an individual could either hold a fixed mindset or growth mindset and not both of them combine. Thus, a fixed mindset represents a mindset that makes an individual believes in his qualities that are considered to be carved in stone and also unlikely to change. However, growth mindset deals with the belief that an individual may adopt a mindset which can grant changes and growth through his effort. In brief, the growth mindset implies the personal endeavor that everyone may have for achieving change and growth (Dweck, 2006).

Individual response to the surrounding world is guiding by the influence those mindsets have on him. Therefore this influence describes whether an individual responds to challenges, effort, obstacles and the success of others in a consciously or an unconsciously manner. According to Johnson(2009), a person with low confidence and fixed mindset will come out with low-performance goals as results. Therefore the person will face challenges in a helpless characteristics manner pattern of typical behaviors, feelings, and thoughts. Meanwhile, a person with growth mindset believes that he can succeed and face challenges through the adoption of learning goals. Researchers in need to further exploration of mindsets should consider the research that has most contributed to the understanding of fixed and growth mindset as the starting point of their studies (Rucker \& Galinsky, 2016).

\subsection{Perception of entrepreneurial mindset through education}

According to Mitchell(2007), the field of entrepreneurship through management practices has developed the mindset of a researcher seeking to promote technical and business opportunities within the corporation. Therefore adopting an entrepreneurial mindset helps in challenge recognition and also set the researcher up to overcome those challenges. Thus, the author highlights the importance of leaning at least one course in entrepreneurship field. More than $60 \%$ of U.S colleges and universities offer at least one course in entrepreneurship to facilitate the development of entrepreneurial intention of their students and gain entrepreneurial experience during their youngest ages. The authors argue that the entrepreneurial experience and mindset are an invaluable guide to the young industrial researcher as it legitimizes many of the best management practices needed to capitalize on the technological opportunity.

The investigation of the study base on a sample of 242 business school students reveals that implementing entrepreneurial mindset is more correlated to entrepreneurial activities compared to elaborating one(Mathisen \& Arnulf, 2013). This fact demonstrates the non-relationship between elaborating entrepreneurial mindset and the entrepreneurial activities. According to the result, individuals with implementing an entrepreneurial mindset are susceptible to increase their entrepreneurial activities. It means that implementing entrepreneurial mindset lead an individual to take entrepreneurial action under uncertainty. Meanwhile, individuals with elaborating mindset may collapse between the intentions to become an entrepreneur and taking the actions to be an entrepreneur. Thus, more cognitive activity and doubt become the challenges of individuals that are adopting elaborating mindsets. Mathisen \& Arnulf(2013)rely on revealing that the difference between analysis and action, made in the mindsets of entrepreneurs is discernible. Thus, implementing mindset which is referred to the decisive actions strategies are superior to the elaborating mindsets which are qualified to be the analytical thinking of an entrepreneur Bellotti et al. (2014)elaborate on the benefit that adopting a serious game in a university can bring to the development of students entrepreneurial mindset. This study was based on the experience gain by the researchers under the eSG project. The primary objective of the eSG project was to make students get familiar with the basic concept of entrepreneurship and the management theory of the company through continuous practical stance.

La Guardia, Gentile, Dal Grande, Ottaviano, \& Allegra(2014) demonstrate how important entrepreneurial education has driven the development of an entrepreneurial mindset of young students. Entrepreneurial education plays multiple roles in the process of acquiring knowledge and skills for entrepreneurial activities by being a method of learning as well as a subject of learning. The development of a young student's entrepreneurial mindset being the primary purpose of the research, the authors emphasizes its research on the PNPV learning model and experiential learning theory (ETL). Thus, based on a serious game the learning motivation of students can considerably increase and also have a valuable impact on classroom education and the training program. 
The article portrays a mixed model grounded on the utilization of a serious game to improve entrepreneurial skills and knowledge among young students. Both the model and the game were expounded and developed by taking into consideration the model of an EU-funded project. The project titled I can ...I cannot ...I got from the PNPV project was mainly to introduce and stimulate the entrepreneurial mindset of young students with special regards to small business, cooperatives, and social businesses. The researchers Lindh \& Thorgren(2015) elaborates on what policy directions for training and development of young people's entrepreneurial mindsets and characteristics mean in practice by reviewing the antecedents of entrepreneurial traits that appear in business and education contexts. The study reveals that although an entrepreneurial mindset is defined as "the ability to sense, act, and mobilize under uncertain conditions" (Haynie, Shepherd, Mosakowski and Earley, 2010) in entrepreneurship and business literature, its meaning in education literature is unclear regarding both what it means in practice and what strategies and practices foster such mindsets.

The idea of an entrepreneurial mindset in business literature is founded on the cognitive process of how people perceive, connect, and process information about the self, others, tasks, and uncertain environments. Education contexts highlight teachers' attitudes and behaviors or learning environments, as the most relevant factors. By comparing antecedents of an entrepreneurial mindset in business and education contexts, the components of entrepreneurial characteristics emerge as essential to fostering an entrepreneurial mindset, rather than nurturing the features themselves(Lindh \& Thorgren, 2015).

\subsection{Dimensions and emerging characteristics of entrepreneurial mindset}

Various dimensions have been discussed by several researchers to investigate the measurement process of an entrepreneurial mindset. Table 2 regroups every dimension of an entrepreneurial mindset that has been the object of investigation in the process of entrepreneurial mindset measurement. Depending on the focus of the research, it is undeniable that various tools have been used to measure specific dimensions of the entrepreneurial mindset. Commarmond (2017) formulated a quantitative scale to gauge an entrepreneurial mindset with the help of those dimensions extracted from previous works of literature. Each element is followed by a specific number which represents the appearance times in a literature review. From the previous studies conducted by scholars, eleven (11) key themes have been identified as the core characteristics of an entrepreneurial mindset. These components are qualified as emerging features of the entrepreneurial mindset that are relevant to define and have a better understanding of this concept. Multiple authors have provided in-depth learning of each characteristic in their works. (See table 3)

\subsection{Measurement for the entrepreneurial mindset}

Davis et al. (2016)investigate a research study on developing a new measure of entrepreneurial mindset by looking at the previous research done by various authors. According to previous literature, scholars focus much more on personality traits instrument to attempt to measure individual characteristics associated with entrepreneurial intention and behavior. Therefore personal instruments such as the five-factor model FFM (Costa \& McCrae, 1992), the 16PF(Cattell, Eber, \& Tatsuoka, 1970), general enterprising tendency (GET) by Durham University Business School (D.U.B.S, 1988), entrepreneurial attitude scale EAS (Robinson, Stimpson, Heufner, \& Hunt, 1991), Measure of entrepreneurial bent and abilities META (Ahmetoglu, Leutner, \& Chamorro-Premuzic, 2011), were the focal point of many research articles which deals with the measurement of entrepreneurial mindset as a central topic. Each personality instrument has provided a theoretical context that allows the researcher to comprehend the role of specific traits. Entrepreneurial mindset by definition is the constellation of motives skills and thought process that differentiates entrepreneur to non-entrepreneurs and that contribute to entrepreneurial success. However, based on the 14 major scales, Haynie, Shepherd, Mosakowski and Earley (2010) designed the entrepreneurial mindset profile (EMP) which seeks to measure entrepreneurial mindset more comprehensively compare to the previous personality instrument. The personality traits of the EMP are undoubtedly composed of seven (7) elements that are independence, limited structure, non-conformity, action orientation, passion and need to achieve. Meanwhile, the skills items of the EMP are future focus, idea generation, execution, self-confidence, persistence, and interpersonal sensitivity.

The use of EMP can be more beneficial in important perspective. EMP will benefit to any organization in need of supporting entrepreneurial activities among their employees. It will also provide valuable feedback that helps an organization in the formation of their entrepreneurial teams. In the educational sector, the use of EMP will facilitate the understanding of students of the entrepreneurial concepts and also the perception of their unique style.In collaboration with Allan Gray OrbisfoundationCommarmond (2017)wrote a review article titled "in pursuit of a better understanding and measure for the entrepreneurial mindset." In this review paper, they provide the necessaries information of what has been discussed so far by several authors on the topic of an entrepreneurial mindset. Regarding the measure of the entrepreneurial mindset, they came out with the conclusion that the currents tools show some limits. 
Therefore based on that limitation they proposed to develop a quantitative survey with the intention of it being piloted, tested and refined in South Africa and later on replicated in other countries. According to their studies, they will propose a different survey from the previous one which will measure their identified dimensions base on their proposed definition of an entrepreneurial mindset(Commarmond, 2017).

From the previous literature, they found that several researchers came out with its definition of entrepreneurial mindset by adding their own unique take of this concept. Therefore a common understanding entrepreneurial mindset emerges where it relates to how one's thinking or state of mind (conscious or sub-conscious) or the lens through which one sees the world (Reed \& Stoltz, 2011)influences one's propensity for entrepreneurial activities and outcomes. Throughout deep research, they will determine either go for a quantitative survey using Likert scale question or semantic differential questions. But this quantitative survey will include relevant demographics questions such as; age, gender, level of education, employment and vocational status to help differentiate between the core features.

\subsection{Others contribution to the entrepreneurial mindset literature}

Now as never before, familiar challenges require bold, novel approaches. Registered dietitians will benefit by cultivating an entrepreneurial mindset that involves being comfortable with uncertainty, learning to take calculated risks, and daring to try it (Matheson, 2013). An entrepreneur is someone who takes risks to create something new, usually in business. But the entrepreneurial mindset is available to anyone prepared to rely only on their abilities for their economic security and expect no opportunity without first creating value for others. In this article titled "cultivating an entrepreneurial mindset," she shared what she called success formula to be an entrepreneur and cultivate an entrepreneurial mindset. This formula was elaborated into five (5) steps that are being well prepared, having an international network of colleagues, being a self-directed learner, creating a business that is sustainable and has a key relationship(Matheson, 2013).

Therefore she believes that adopting an entrepreneurial mindset is the way forward to be who you are; to be the best that you can and want to be. When you can create your opportunities, you never need to be fearful again. Try achieving intended results. As you are successful and gain confidence, do it! Dare to take a risk; dare to do what you were meant to do, to become who you were expected to be. Pfeifer, Sarlija, \& Susac(2016)researched to determine the relationship between four (4) variables that are entrepreneurial identity, entrepreneurial self-efficacy, social norms, and personal business exposure. The relationship between those variable has been perceived as a paramount shaper of an entrepreneurial mindset. In their paper, they came out with the implication that self-efficacy and entrepreneurial identity mediate the number of personal, contextual or situational factors, including the educational impact on intention. In his article titled as "the counter-conventional mindset of entrepreneur" Mullins(2017) conclude that six (6) common patterns labeled the counter-conventional mindset and behaviors. Those patterns are (1) yes, we can (2) beg, borrow or steal, (3) think narrow, not broad, (4) problem first, not product-first logic, (5) No is something waiting to be turned into Yes and (6) ask for the cash and ride the float. According to Mullins(2017), an individual can be an entrepreneur by learning these six model of entrepreneurial thought and action. Therefore this is a sign that entrepreneurs are made and not only born.

\section{Conclusion and Future research}

This review paper is a combined study of both the idea of entrepreneurship and entrepreneurial mindset concept from various perspectives and viewpoints of several scholars. This article is a reference to what has been done so far in the process of understanding entrepreneurship as an emergent field. Moving forward the definition of the term entrepreneur is the first step to investigate the study on entrepreneurship. Therefore this article provides relevant information on who and what an entrepreneur is. A tabulated list of entrepreneur or entrepreneurship definition has been granted based on the thoughts of several researchers. Each author contributed to the evolution of the field by emphasizing on the element that he founded more valuable while elaborating the definition of entrepreneur. This paper provides relevant information on the cognitive aspect and personality traits of understanding entrepreneurial mindset theory. It also revealed the model that has been used by researchers to measure mindset and even entrepreneurial mindset base on a tabulated list of dimensions from the literature review. Through the success and limit of those multitude model, a quantitative survey has been recommended as a universal measure for the entrepreneurial mindset. Information in this article has been presented to the public and can be used by any organization, any individual and any researchers who have shown interest in the field of entrepreneurship especially in the process of understanding entrepreneur mindset. This paper combined both entrepreneur and entrepreneurial mindset concept and presented a broad overview of these two concepts that can be used to further research in the same area.Entrepreneurship should not be the only concern of students or people with higher education. Everyone should have the chance of building an entrepreneurship career because the entrepreneurs are the mainstay in the economic development of the country. 
The fact is that rural area is neglected whenever we talk about government policies and regulations to foster entrepreneurship in the rural area. However rural communities represent also a human resource that contributes to the economic growth of the country. Therefore what can be done to help rural communities increase entrepreneurial activities in the rural area? How can entrepreneurial mindset be developed within a rural area? What mechanism to be used to educate rural communities who present high rate of illiterate people?

\section{Tables and figures}

Table1:Definition of entrepreneur(ship) retrieved from $($ Bosman \& Fernhaber, 2018; Dissanayake, 2013)

\begin{tabular}{|c|c|c|}
\hline Authors (origin) & Definition & Emphasize on \\
\hline $\begin{array}{l}\text { Richard Cantillon } \\
(1755)\end{array}$ & $\begin{array}{l}\text { An Entrepreneur is described as an individual who purchases raw material as a } \\
\text { known price and sells it at an unknown amount. }\end{array}$ & Risk \\
\hline $\begin{array}{l}\text { Jean Baptist Say } \\
(1800 \text { s) }\end{array}$ & $\begin{array}{l}\text { Entrepreneur shifts economic resources out of an area of lower and into an area } \\
\text { of higher productivity and greater yield }\end{array}$ & Create value \\
\hline $\begin{array}{l}\text { Joseph Schumpeter } \\
\text { (1942) }\end{array}$ & $\begin{array}{l}\text { The function of entrepreneur is to reform or revolutionize the patterns of } \\
\text { productivity... by exploiting an invention or, more generally, an untried } \\
\text { technological possibility for producing a new commodity or producing an old } \\
\text { one in a new way, by opening up a new source of supply of materials or a new } \\
\text { outlet for products, by reorganizing an industry and so on }\end{array}$ & $\begin{array}{l}\text { Change agent or } \\
\text { innovator } \\
\text { Creative } \\
\text { destruction }\end{array}$ \\
\hline McClelland (1961) & $\begin{array}{l}\text { An entrepreneur is a person with higher achievement and an energetic, moderate } \\
\text { risk taker. }\end{array}$ & $\begin{array}{l}\text { High Achiever } \\
\text { Risk }\end{array}$ \\
\hline Shapero (1975) & $\begin{array}{l}\text { Entrepreneur takes initiative, organize some social and economic mechanisms } \\
\text { and accept risks of failure. }\end{array}$ & $\begin{array}{l}\text { Initiative taker } \\
\text { Organizer }\end{array}$ \\
\hline Kirzner(1978) & $\begin{array}{l}\text { Entrepreneur recognized and acts upon a market opportunity. The entrepreneur } \\
\text { is essentially an arbitrageur. }\end{array}$ & $\begin{array}{l}\text { Arbitrageur } \\
\text { Opportunity }\end{array}$ \\
\hline $\begin{array}{l}\text { Howard } \\
\text { Stephenson (1983) }\end{array}$ & The pursuit of opportunity without regard to resources currently controlled & $\begin{array}{l}\text { Resourcefulness } \\
\text { and uncertainty }\end{array}$ \\
\hline $\begin{array}{l}\text { Carland et al. } \\
\text { (1984) }\end{array}$ & $\begin{array}{l}\text { The entrepreneur is characterized principally by innovative behavior and will } \\
\text { employ strategic management practices in the business. }\end{array}$ & Strategic thinking \\
\hline $\begin{array}{l}\text { Kao and Stevenson } \\
(1985)\end{array}$ & $\begin{array}{l}\text { The entrepreneur is an attempt to create value through recognition of business } \\
\text { opportunities }\end{array}$ & $\begin{array}{l}\text { Value creation } \\
\text { Opportunity }\end{array}$ \\
\hline $\begin{array}{l}\text { Peter Drucker } \\
(1985 \mathrm{a}, \mathrm{b})\end{array}$ & $\begin{array}{l}\text { Entrepreneur always pursuits for change, responds to it and exploit it as an } \\
\text { opportunity }\end{array}$ & Opportunity \\
\hline $\begin{array}{l}\text { Low and } \\
\text { MacMillan (1988) }\end{array}$ & Entrepreneurship is the creation of new organization. & Venture creation \\
\hline Gartner (1988) & $\begin{array}{l}\text { Entrepreneurship is a purposeful activity to initiate, maintain and aggrandize a } \\
\text { profit-oriented business. }\end{array}$ & Business profit \\
\hline $\begin{array}{l}\text { Hisrisch and Peters } \\
(1989)\end{array}$ & $\begin{array}{l}\text { Entrepreneurship is the process of creating something different with the value by } \\
\text { devoting the necessary time and effort; assuming the accompanying financial, } \\
\text { psychological, and social risks, and receiving the resulting rewards of monetary } \\
\text { and personal satisfaction. }\end{array}$ & $\begin{array}{l}\text { Innovation } \\
\text { Valued added } \\
\text { Risk } \\
\text { Profit }\end{array}$ \\
\hline $\begin{array}{l}\text { Lumpkin and Dess } \\
\text { (1996) }\end{array}$ & Entrepreneurship is the creation of new enterprise & Venture creation \\
\hline $\begin{array}{l}\text { Shane and } \\
\text { Venkataraman } \\
\text { (2000) }\end{array}$ & Discovering, evaluation and exploitation of an opportunity & $\begin{array}{l}\text { Entrepreneurship as } \\
\text { a process }\end{array}$ \\
\hline Davidsson (2004) & The phenomenon of entrepreneurship really consists of new entry & New Market entry \\
\hline Mohanty (2005) & $\begin{array}{l}\text { Entrepreneurship is defined as the purposeful activity of an individual or a group } \\
\text { of associated individuals undertake to initiate, maintain, or earn profit by } \\
\text { production and distribution of economic goods and services. }\end{array}$ & $\begin{array}{l}\text { Initiative taker } \\
\text { Profit maker }\end{array}$ \\
\hline $\begin{array}{l}\text { SarasSarasvathy } \\
(2005)\end{array}$ & Entrepreneurial thinking differs from managerial thinking and strategic thinking & Effectuation \\
\hline $\begin{array}{l}\text { Timmons and } \\
\text { Spinelli (2008) }\end{array}$ & $\begin{array}{l}\text { Entrepreneurship is a way of thinking, reasoning, and acting that is opportunity } \\
\text { obsessed, holistic in approach and leadership balanced. }\end{array}$ & $\begin{array}{l}\text { Leader } \\
\text { Holistic } \\
\text { Persistent } \\
\text { committed }\end{array}$ \\
\hline
\end{tabular}


Through the evaluation of the above table, we observe that seven elements or components figured in most of the definition provided by those prominent authors. Hence we should consider these seven elements while formulating a definition of entrepreneur or entrepreneurship.

Risk ***

Innovator **

Opportunity recognition $* * * *$

Business profit ***

Note: * represent the number of times cited in the definition value creation $* * *$

initiative taker $* *$

venture creation $* *$

Fig 1: Main elements cited in the definition of entrepreneur (ship) by scholars

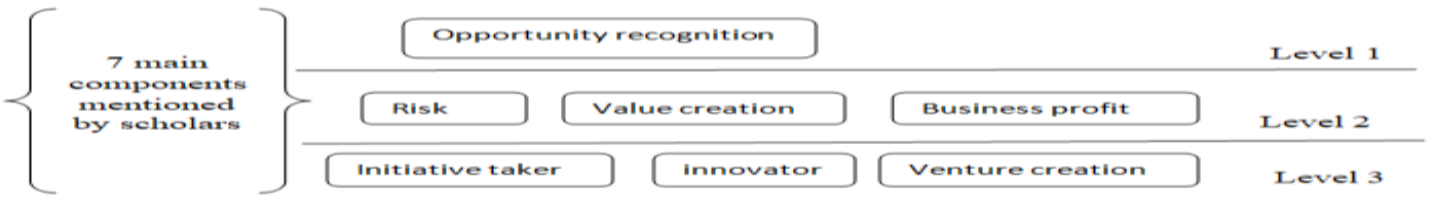


Table 2: Dimensions of entrepreneurial mindset:Adapted from(Commarmond, 2017)

\begin{tabular}{|c|c|}
\hline $\begin{array}{lllll}\begin{array}{l}\text { Emergent } \\
\text { mindset }\end{array} & \text { characteristics of an entrepreneurial } \\
\end{array}$ & Authors \\
\hline Lifelong learning and openness to change & $\begin{array}{l}\text { (Dweck et al., 1995) ; Putta (2014) } \\
\text { Mooradian et al. (2016) } \\
\text { (Totem Inc., 2015). Sarasvathy (2001) } \\
\text { Stauffer (2015); Moberg et al. (2014) } \\
\text { (Taulbert and Schoeniger, 2010) }\end{array}$ \\
\hline Engagement in a complex and uncertain world & $\begin{array}{l}\text { Dweck et al., 1995) ;(Sarasvathy, 2001) } \\
\text { (Totem Inc., 2015); Putta (2014) }\end{array}$ \\
\hline Creative and innovative approaches to problem-solving & $\begin{array}{l}\text { Valerio et al., 2014). } \\
\text { (Kirton, 1976); (Solomon and Winslow, 1988); } \\
\text { (Pizarro,2014); Moberg et al. (2014) } \\
\text { (Mooradian et al., 2016);(Davis et al., 2016) } \\
\text { (Stauffer, 2015) }\end{array}$ \\
\hline $\begin{array}{l}\text { Belief and confidence in one's own capacity and } \\
\text { competency to be entrepreneurial }\end{array}$ & $\begin{array}{l}\text { Valerio et al. (2014) } \\
\text { (Midgley et al., 2000; Moberg et al., 2014; Mooradian et } \\
\text { al., 2016);Mitchell and Shepherd (2010) Pfeifer et al. } \\
\text { (2016) } \\
\text { (Taulbert and Schoeniger, } 2010\end{array}$ \\
\hline $\begin{array}{l}\text { Desire, motivation, and intention to } \\
\text { entrepreneurship and behave entrepreneurially }\end{array}$ & $\begin{array}{l}\text { (Taulbert and Schoeniger, } 2010 \text { );(Valerio et al., 2014) } \\
\text { Moberg et al. (2014) ;(Mooradian et al., 2016) } \\
\text { (Davis et al., 2016); (Stauffer, 2015) } \\
\text { Pfeifer et al. (2016); Putta (2014 }\end{array}$ \\
\hline $\begin{array}{l}\text { Taking the initiative and personal responsibility for } \\
\text { actions }\end{array}$ & $\begin{array}{l}\text { (Midgley et al., 2000); (Moberg et al., 2014; Mooradian et } \\
\text { al., 2016); Pfeifer et al. (2016) } \\
\text { (Taulbert and Schoeniger, 2010); (Davis et al., 2016) } \\
\text { (Stauffer, 2015); (Totem Inc., 2015 }\end{array}$ \\
\hline $\begin{array}{l}\text { A pursuit of goal-attainment through personal mastery } \\
\text { and value-creation }\end{array}$ & $\begin{array}{l}\text { Begley and Boyd (1986); Putta (2014) } \\
\text { (Midgley et al., 2000);(Moberg et al., 2014); (Mooradian } \\
\text { et al., 2016); (Dweck et al., 1995); (Totem Inc., } 2015\end{array}$ \\
\hline Recognizing opportunities & $\begin{array}{l}\text { (Taulbert and Schoeniger, 2010; Putta, 2014) } \\
\text { Sarasvathy (2001); (Totem Inc., 2015). Davis et al. (2016) }\end{array}$ \\
\hline Grit and perseverance in the face of challenges & $\begin{array}{l}\text { (Dweck et al., 1995); (Putta, 2014); Dweck (2006) } \\
\text { (Moberg et al., 2014; Totem Inc., 2015; Davis et al., } \\
\text { 2016); (Mooradian et al., 2016; Duckworth et al., 2007); } \\
\text { Valerio et al. (2014) ; (Sarasvathy, 2001) ;Schoeniger } \\
\text { (2010); Mitchell and Shepherd (2010) }\end{array}$ \\
\hline Taking risks that lead to learning, growth, and value & $\begin{array}{l}\text { Valerio et al. (2014) and Moberg et al. (2014) } \\
\text { Sarasvathy (2001); (Caird, 1991; Cunningham and } \\
\text { Lischeron, 1991; Drucker, 1985); (Putta, 2014); (Davis et } \\
\text { al., 2016); Mooradian et al. (2016); }\end{array}$ \\
\hline A belief in one's ability to influence & $\begin{array}{l}\text { Taulbert and Schoeniger (2010); Sarasvathy (2001) } \\
\text { (Moberg et al., 2014); Davis et al. (2016); Dweck (2016) }\end{array}$ \\
\hline
\end{tabular}


Table 3: Emerging characteristics of entrepreneurial mindset Retrieved from (Commarmond, 2017)

\begin{tabular}{|c|c|}
\hline Ability to exploit contingencies (1) & Independence (2) \\
\hline Achievement orientation (1) & Initiative (2) \\
\hline Action orientation (2) & Innovation (2) \\
\hline Adaptability (2) & Insane hunger to succeed (1) \\
\hline Ambition (2) & Internal locus of control (4) \\
\hline Antagonism (1) & Interpersonal sensitivity (1) \\
\hline Autonomy (1) & Iterative (1) \\
\hline Benefiting others (1) & Learns from criticism (1) \\
\hline Calculated risk-taking (1) & Malleable behavior (1) \\
\hline Conscientiousness (2) & Mastery-orientated (3) \\
\hline Consistent passion and interest (1) & Mediational judgement (1) \\
\hline $\begin{array}{l}\text { Context of relevance: More dynamic, nonlinear, and } \\
\text { ecological (1) }\end{array}$ & Motivation (3) \\
\hline Contextual goal-orientation (1) & $\begin{array}{l}\text { Nature of the unknown: Focus on the controllable aspects of } \\
\text { an } \\
\text { unpredictable future (1) }\end{array}$ \\
\hline Creativity and imagination (3) & Need for achievement (3) \\
\hline Curiosity (1) & Need for empowerment (1) \\
\hline Dealing with uncertainty (1) & Neuroticism (1) \\
\hline $\begin{array}{l}\text { Decision Making: Decisions made by what one is } \\
\text { willing to risk (1) }\end{array}$ & Nonconformity (1) \\
\hline $\begin{array}{l}\text { Decision Making: Explores what else could be } \\
\text { possible } \\
\text { with given means (1) }\end{array}$ & Open to collaborate and partner (1) \\
\hline $\begin{array}{l}\text { Decision Making: Focused on the process and } \\
\text { adaptable learning journey (1) }\end{array}$ & Open to feedback (1) \\
\hline Desire to influence others (3) & Open to experiences (1) \\
\hline Determination (2) & Opportunity recognition (2) \\
\hline Dynamism and complexity (1) & Optimism (1) \\
\hline Effectual (1) & Passionate (2) \\
\hline Effort-oriented (2) & Passion for entrepreneurship (1) \\
\hline Embrace challenges (1) & Persistence (4) \\
\hline Entrepreneurial identity aspiration (1) & Planning ahead (1) \\
\hline Entrepreneurial intention (1) & Preference for a limited structure (1) \\
\hline Entrepreneurial motivation (1) & Probabilistic (1) \\
\hline Entrepreneurial self-efficacy (3) & Recognize Patterns and Linkages (1) \\
\hline Extraversion (1) & Reflective (1) \\
\hline Feeling of empowerment (1) & Resilience (1) \\
\hline $\begin{array}{l}\text { Finds lessons and inspiration in the success of } \\
\text { others } \\
\text { (1) }\end{array}$ & Resourcefulness (2) \\
\hline Flexibility (2) & Responds rather than reacts (1) \\
\hline Future-focused (1) & Risk-orientation (4) \\
\hline General self-efficacy (3) & Self-belief and self-confidence related (6) \\
\hline Goal-oriented (1) & Tenacious (1) \\
\hline Goals set for learning sake (1) & Tolerance for failure (3) \\
\hline Idea generation (1) & $\begin{array}{l}\text { Underlying logic: To the extent, we can control the future, } \\
\text { we do } \\
\text { not need to predict it (1) }\end{array}$ \\
\hline
\end{tabular}




\section{Project funds}

(1) Self -organized cluster entrepreneurship behavior reform, evolution and promotion strategies study(No.16BGL028), China National Social Science Foundation;

(2) Perception of fairness in self-organized mass entrepreneurship (4061160023), Jiangsu Province Graduate Scientific Research Innovation Project;

(3) Interactive effect between Self-Organized Innovation and Industrial cluster, Jiangsu Province Graduate Scientific Research Innovation Project. (KYCX17_1746).

\section{References}

Ahmetoglu, G., Leutner, F., \& Chamorro-Premuzic, T. (2011). EQ-nomics: Understanding the relationship between individual differences in trait emotional intelligence and entrepreneurship. Personality and Individual Differences, 51, 1028-1033. doi: 10.1016/j.paid.2011.08.016

Audretsch, D. B., Kuratko, D. F., \& Link, A. N. (2016). Dynamic entrepreneurship and technology-based innovation. Journal of Evolutionary Economics, 26(3), 603-620.

Baron, R. A. (2004). The cognitive perspective: a valuable tool for answering entrepreneurship's basic "why" questions. Journal of business venture, 19, 221-239. doi: 10.1016/S0883-9026(03)00008-9

Bellotti, F., Berta, R., De Gloria, A., Lavagnino, E., Antonaci, A., Dagnino, F., . . Mayer, I. S. (2014). Serious games and the development of an entrepreneurial mindset in higher education engineering students. Entertainment Computing, 5(4), 357-366. doi: https://doi.org/10.1016/j.entcom.2014.07.003

Bosman, L., \& Fernhaber, S. (2018). Teaching the Entrepreneurial Mindset to Engineers. Springer International Publishing AG. doi: 10.1007/978-3-319-61412-0_2

Brandstätter, H. (2011). Personality aspects of entrepreneurship: A look at five meta-analyses. Personality and Individual Differences, 51, 222-230. doi: 10.1016/j.paid.2010.07.007

Bruton, G. D., Ahlstrom, D., \& Obloj, K. (2008). Entrepreneurship in emerging economies: where are we today and where should the research go in the future. Entrepreneurship Theory and Practice, 32(1), 1-14.

Busenitz, L. W., West Iii, G. P., Shepherd, D. A., Nelson, T., Chandler, G. N., \& Zacharakis, A. (2003). Entrepreneurship research in emergence: Past trends and future directions. Journal of Management, 29(3), 285-308.

Cantillon, R. (1755). Essai sur la nature du commerce en général, London: Fetcher Gyler Also: Edited with an English translation by Henry Higgs, London:MacMillan (1931). The manuscript was probably written around 1720 and was published after Cantillon was murdered in 1734. It is believed that he himself wrote the French and English versions.

Cattell, R. B., Eber, H. W., \& Tatsuoka, M. M. (1970). Handbook for the Sixteen Personality Factor Questionnaire (16PF) Champaign, IL: Institute for Personality and Ability Testing.

Chinonye, 1. M., \& Akinlabi, M. (2014). Entrepreneurship curriculum and pedagogical challenges in captivating studentse interest towards entrepreneurship education. Research Journal of Economics and Business Studies, $4(1), 1-111$.

Commarmond, I. (2017). In pursuit of a better understanding of and measure for entrepreneurial mindset. Retrieved from Cape Town, South Africa. www.allangrayorbis.org.

Costa, P. T., \& McCrae, R. (1992). NEO-PI-R and NEO-FFI professional manual. Odessa, FL. Psychological Assessment Resources.

Cromie, S. (2000). Assessing entrepreneurial inclinations: Some approaches and empirical evidence. European journal of work and organizational psychology, 9, 7-30. doi: 10.1080/135943200398030

D.U.B.S. (1988). General enterprising test (GET). Durham, UK: Author.

Davis, H., Hall, A., \& Mayer, I. S. (2016). Developing a new measure of entrepreneurial mindset: reliability, validity, and implications for practitioners. Consulting Psychology Journal: Practice and Research, 68(1), 21-48. doi: $10.1037 / \mathrm{cpb} 0000045$

Déry, R., \& Toulouse, J.-M. (1996). Social Structuration of the Field of Entrepreneurship: A Case Study. Canadian Journal of Administrative Sciences / Revue Canadienne des Sciences de l'Administration, 13(4), 285-305. doi: doi:10.1111/j.1936-4490.1996.tb00739.x

Dhliwayo, S., \& Van Vuuren, J. J. (2007). 'The strategic entrepreneurial thinking imperative'.Acta Com, 7, 123-134.

Dissanayake, S. (2013). Entrepreneurship and the Entrepreneur: A Synthesis View. MPRA, 1-6.

Dweck, C. S. (2006). Mindset: The new psychology of success. Random House, New York. 
Dweck, C. S., \& Leggett, E. L. (1988). A social-cognitive approach to motivation and personality. Psychologyrevue, $95,256$.

Faltin, G. (2007). The successful entrepreneurs start as an artist and composer:German Industry and Commerce, Berlin.

Fayolle, A. (2012). Lexicon.ft.com [WWW Document]. Financ. Times Lex. URLhttp://lexicon.ft.com/Term?term=entrepreneurial-mindset (accessed 11.12.16).

Haynie, J. M., Shepherd, D., Mosakowski, E., \& Earley, P. C. (2010). A situated metacognitive model of the entrepreneurial mindset. Journal of Business Venturing, 25(2), 217-229. doi: https://doi.org/10.1016/j.jbusvent.2008.10.001

Hindle, K., \& Moroz, P. (2010). "Indigenous entrepreneurship as a research field: developing a definitional framework from the emerging canon".International Entrepreneurship and Management Journal, 6(4), 357-385.

Ireland, R. D., Hitt, M. A., \& Sirmon, D. G. (2003). A Model of Strategic Entrepreneurship: The Construct and its Dimensions. Journal of Management, 29(6), 963-989. doi: 10.1016/s0149-2063_03_00086-2

Johnson, D. V. (2009). Growth Mindset as a Predictor of Smoking Cessation. Submitted in partial fulfilment of requirements for the degree doctor of philosophy in urban education the Cleveland State University.

Kuratko, D. F. (2002). Corporate Entrepreneurship: Entrepreneurial development within organisations. London: Thompson South Western.

La Guardia, D., Gentile, M., Dal Grande, V., Ottaviano, S., \& Allegra, M. (2014). A Game based Learning Model for Entrepreneurship Education. Procedia - Social and Behavioral Sciences, 141, 195-199. doi: https://doi.org/10.1016/j.sbspro.2014.05.034

Leutner, F., Ahmetoglu, G., Akhtar, R., \& Chamorro-Premuzic, T. (2014). The relationship between the entrepreneurial personality and the Big Five personality traits. Personality and Individual Differences, 63, 58-63. doi: 10.1016/j.paid.2014.01.042

Lindh, I., \& Thorgren, S. (2015). Learning and teaching entrepreneurial mindsets: bridging research in business and education. In H. Bernice (Ed.), Goal Setting and Personal Development: Teachers' Perspectives, Behavioral Strategies and Impact on Performance (pp. 35-60): Nova Science Publishers, Inc.

Matheson, S. A. (2013). Cultivating an Entrepreneurial Mindset. Canadian Journal of Dietetic Practice and Research, 74(3), 146-149. doi: 10.3148/74.3.2013.146

Mathisen, J.-E., \& Arnulf, J. K. (2013). Competing mindsets in entrepreneurship: The cost of doubt. The International Journal of Management Education, 11(3), 132-141. doi: https://doi.org/10.1016/j.ijme.2013.03.003

Mauer, R., Neergaard, H., \& Kirketerp, A. (2009). Self-Efficacy: Conditioning the Entrepreneurial Mindset (pp. 233257).

McGrath, R. G., \& MacMillan, I. C. (2000). The Entrepreneurial Mindset. Harvard Business School Press.

Midgley, C., Kaplan, A., \& Middleton, M. (2001). Performance-approach goals: Good for what, for whom, under what circumstances, and at what cost? Journal of Educational Psychology, 93, 77-86. doi: 10.1037/00220663.93.1.77

Midgley, C., Maehr, M. L., Hruda, L. Z., Anderman, E., Anderman, L., Freeman, K. E., \& Urdan, T. (2000). Manual for the patterns of adaptive learning scales. Ann Arbor 1001, 48109-1259.

Mitchell, G. R. (2007). Instill the entrepreneurial mindset. Research Technology Management, 50(6), 11-13.

Mitchell, R. K., Smith, B., Seawright, K. W., \& Morse, E. A. (2000). Cross-Cultural Cognitions and the Venture Creation Decision. Academy of Management Journal, 43(5), 974-993. doi: 10.5465/1556422

Mullins, J. (2017). The counter-conventional mindsets of entrepreneurs. Business Horizons, 60(5), 597-601. doi: https://doi.org/10.1016/j.bushor.2017.05.003

Pfeifer, S., Sarlija, N., \& Susac, M. Z. (2016). Shaping the Entrepreneurial Mindset: Entrepreneurial Intentions of Business Students in Croatia. Journal of Small Business Management, 54(1), 102-117. doi: $10.1111 /$ jsbm. 12133

Pollard, V., \& Wilson, E. (2014). THE "ENTREPRENEURIAL MINDSET" IN CREATIVE AND PERFORMING ARTS HIGHER EDUCATION IN AUSTRALIA. Artivate: A Journal of Entrepreneurship in the Arts, 3(1), 322.

Reed, J., \& Stoltz, P. G. (2011). Put your mindset to work. Penguin UK, London.

Robinson, P. B., Stimpson, D. V., Heufner, J. C., \& Hunt, H. K. (1991). An attitude approach to the prediction of entrepreneurship. Entrepreneurship Theory and Practice, 15, 13-31.

Romer, P. M. (1994). The origins of endogenous growth. Journal of Economic Perspectives, 8(1), 3-22.

Rucker, D. D., \& Galinsky, A. D. (2016). Growing beyond growth: Why multiple mindsets matter for consumer behaviour. Journal of Consumer Psychology, 26, 161-164. doi: 10.1016/j.jcps.2015.06.009 
Say, J. B. (1815). Cathéchisme d'économie politique, Maison Mame (1972)); also translation: Catechism of political economy: on familiar conversations on the manner in which wealth is produced, distributed and consumed by society, London: Sherwood (1816).

Say, J. B. (1996). Cours d'économie politique et autresessais, Paris: GF-Flammarion (Selection of main writings).

Schildt, H. (2012). The Field of Entrepreneurship: A Bibliometric Assessment.

Schumpeter, J. A. (1928). Des Unternehmer', in Ludwig Elster et al. (Eds.) Handworterbuch der Staatsvissen-schaften, (fourth edition, Jena, 1928). In: Hartmann, H. (1959) 'Managers and entrepreneurs: a useful distinction', 430431, Administrative Science Quarterly, 3, 3:429-451.

Schumpeter, J. A. (1934). The theory of economic development. Harvard University press, Cambridge.

Schumpeter, J. A. (1954). History of economic analysis, edited by Elizabeth Boody Schumpeter, New York: Oxford University Press; also, London: George Allen \& Unwin (6th printing 1967.

Taylor, F. W. (1947). Scientific Management. Comprising: Shop Management; The Principles of Scientific Management; Testimony before the special House Committee,New York \& London: Harper \& Brothers Publishers.

Thompson, J. L. (2004). The facets of the entrepreneur: identifying entrepreneurial potential. Management Decision, 42(2), 243-258. doi: doi:10.1108/00251740410515861

Welter, F., \& Lasch, F. (2008). Entrepreneurship research in Europe: Taking stock and looking forward. Entrepreneurship Theory and Practice, 32(2), 241-248.

Zhao, H., \& Seibert, S. E. (2006). The Big Five personality dimensions and entrepreneurial status: A meta-analytical review. Journal of Applied Psychology, 91, 259-271. doi: 10.1037/0021-9010.91.2.259 